\title{
Small and Medium Enterprises in Brazil: A Comprehensive Study of the Manager's View of the Business
}

\author{
Fabio Papalardo, L. Claudio Meirelles, \\ José Benedito Sacomano, and Jayme de Aranha Machado \\ Paulista University-UNIP, Post-Graduate Program in Production Engineering, Brazil \\ \{Fabio Papalardo, fabio.eng.unip\} @gmail.com
}

\begin{abstract}
Small and Medium Enterprises (SME) in Brazil are factors of great economic importance, for they represent employment for more than fifty six million people. When we consider the country's overall population of two hundred million inhabitants we can understand the magnitude of such economic segment, and it means that it is responsible for the sustainability of the employment structure. As in any economic activity, it depends on efficiency and that means specialized management, low costs, low waste, high competitiveness: these factors assure the sustainability of such enterprises in the market. Apart from these factors, which are internal to the management, there are external factors that influence the enterprises' performance, such as policies to foster development, financial cost, qualified work force, the tax burden, value of local currency weighted against foreign currencies, and other factors. Management compliant with this matrix of factors is dependent upon the managers' vision. This comprehension by the managers about the different internal and external factors that influence the enterprise shall define the organizational culture that will prevail in this type of enterprises. For this study, we have researched the vision of SME's managers as far as internal and external factors that influence the management of enterprises.
\end{abstract}

Keywords: Small ad Medium Sized Enterprises 1, Sustainability Factors 2, Cultural Factors 3.

\section{Introduction}

Small and Medium Sized Enterprises (SMEs) represent 99\% of the Brazilian enterprises [1]. They are responsible for $20 \%$ of the Gross National Product (GNP) with 320 billion Dollars and generate $60 \%$ of all formal employment posts in Brazil, that is, 56.4 million. These data are by themselves relevant for the Country's economic and social development.

The vision of SMEs managers, the way they see the market, the way they face administration, the importance of these enterprises and above all, the factors necessary to their sustainability, show the possibility of analyzing the segment, as far as its consolidation in the market, according to the time of permanence or survival in the 
market. In Brazil the mortality level is around 25\%, after two years of existence [1]. In the worldwide landscape, Brazil is faring well; best levels are: Slovenia 22\%, Austria $24 \%$, followed by Spain 31\%, Italy 32\%, Portugal $49 \%$ and Holland $50 \%$. Of course, these countries have different markets, with their characteristics and particularities.

Our analysis takes into account factors that influence the performance of SMEs in two aspects, internal factors, that relate to their operations, divisions and functions; as well as external factors, as public policies, the financial market, among others.

The managers' vision are indicative of how they understand the real aspects of SMEs, but not necessarily how SMEs should be managed, and how they understand the policies for development and sustainability of such an important economic sector, as the SMEs are.

\subsection{Theoretic Foundation}

Studies about Small and Medium Sized Enterprises are frequently conducted, due to their importance in the development of countries and regions.

Studies report differences of management in large enterprises and SMEs.

The administration of a SME has its particularities; the greatest difference between large enterprises and SMEs is that the SMEs are concerned with day-to-day operational activities, but large enterprises follow strategic planning [1].

Managers do not realize the economic potential of being responsible to the social issues, to the environment and, as particularly it was studied in the research, to the health of the employees. Although the first responsibility of a manager is generating profits, companies can at the same time contribute to social and environmental objectives, through integrating corporate social responsibility as a strategic investment into their core business strategy, their management instruments and their operations [2].

Another particularity of SMEs is the cultural difficulty of cooperation and the establishment of Local Production Consultations, which, a relationship of cooperation among SMEs would ease up access to resources one does not have, as well as would strengthen up one's own resources and increase the potential of an enterprise's strong aspects. Besides, cooperation between enterprises can represent a manner of developing SMEs competitive advantage and such may become a link to competitiveness [3].

The funds raised are used by small and medium companies in their development, the most innovative, counseling and training staff. In the development of business by SMEs are most helpful database consulting, sample manuals for obtaining financial support and to promote innovation. The current business environment is referred to as hyper-competitive and global. If there are any changes in it, these will be permanent rather of the crisis character than towards certainty and possibility prediction of future development [4].

Informational barriers are the core bottleneck inhibiting energy efficiency improvements in SME sector. Financial and organizational barriers also influence a company's energy saving activities. Data point out three additional barriers to energy saving activities: the role of family ownership structures, lax enforcement of govern- 
ment regulations and the absence of government support as well as a lack of skilled labor [5].

All these factors form a picture that must be studied in all its particularities, so that policies and management systems may be implemented.

\section{Methodology}

The methodology presented used the comprehensive method, the comprehensive analysis encourages the integration of the largest possible number of elements and connections. This method identifies opinions of managers of small and medium sized enterprises, as far as their sustainability in the Brazilian market [6]. The research, of exploratory character, used the study of a case with data collection through a non structured interview with questions and answers.

Non structured interviews identified the factors the managers considered relevant for the administration of small and medium sizes Brazilian enterprises.

The theme of this proposal represents a contribution to the ways a manager of a small and medium sized Brazilian enterprise evaluates a business.

The research was conducted using the Likert measuring scale for relevant sustainability factors of the enterprise in the market, as well as an evaluation after attributing points 0 to 10 applicable to the enterprise's sectors, depending on each sector importance for administration and performance.

As far as the Likert scale, the number of possible answers is five, keeping in mind that the possibility of answers can be odd or even: an odd answer allows the respondent, for any reason, to keep himself neuter; an even answer does not allow it - the respondent has to take a position.

The format was: 1 - Of no relevance; 2 - Of some relevance; 3 - Relevant; 4 - Of much relevance; 5 - Necessary.

Research was conducted in four areas: Region of Fortaleza and Juazeiro do Norte, in the State of Ceará; the region of Montes Claros and the region of Araxá, in the State of Minas Gerais. The regions of Araxá and Montes Claros, although they both are in the State of Minas Gerais, have different characteristics as far as entrepreneurial culture: Araxá is in the Triângulo Mineiro, an area under the influence of the Southeast Region, and Montes Claros is in the northern part of the State of Minas Gerais, culturally connected to the Region of the Sertão Mineiro and Southern Bahia. The region of Fortaleza and Juazeiro do Norte has cultural aspects typically of the Northeastern Region.

This diversity has the objective of avoiding any regional aspect to the research.

\section{Results and Discussion}

Fifty seven enterprises were researched in the four regions, and the companies were classified as wholesalers, retailers, industry and services. 


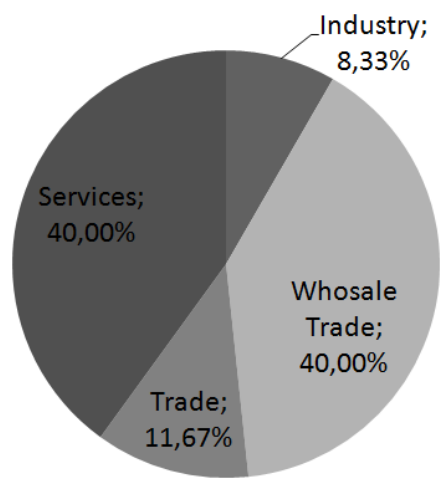

Fig. 1. Profile of the Researched Enterprises

Non structured interviews indicated that the areas of activity considered essential by the managers of small and medium sized enterprises are:

Sales: The volume of sales of products or services is important.

Purchases: Researched enterprises buy products, raw materials and/or labor services.

Production: Transformation of primary products in final products, as well as delivery services to the market.

Planning: Operational and strategic planning.

Product: Product sold or service performed.

Costs: Purchases, and direct and indirect expenses with labor, and taxes.

Administrative: General management of the business, as a sustainability tool of the enterprise in the market.

These are the sectors that matter to the managers' vision, related to the enterprise's Internal Factors.

In this portion of the research what becomes evident is the scale of values perceived by the managers in the different sectors and activities of the enterprises (figure 2).

We can see that, according to the vision of the managers, to have a product of competitive performance is the most important factor, with 7.89 points in a 0 to 10 scale.

The second factor is sales, with 7.75 points, followed by the business administration with 7.52, purchases 7.51, costs 7.32, planning 7.25 and production 6.76 .

A detailed vision per region (Table 1).

Enterprise's sectors: products, sales, administration, purchasing, costs, business planning, production, others, none; average.

The second half of the research shows external factors, which, according to the vision of the managers, affect the performance and sustainability of the enterprises. 
They are:

Public policies for development and growth of Small and Medium Sized Enterprises.

The financial establishment banks and credit institutions the serve the Small and Medium Sized Enterprise.

Academic or technical education for the workers at Small and Medium Sized Enterprises.

Access to new ideas, congresses, fairs and specialized training, in order to be prepared to face the market's demands.

Contribution and support from class associations and non-governmental agencies for development of Small and Medium Sized Enterprises

Employment posts generated in Small and Medium Sized Enterprises in the national scenario.

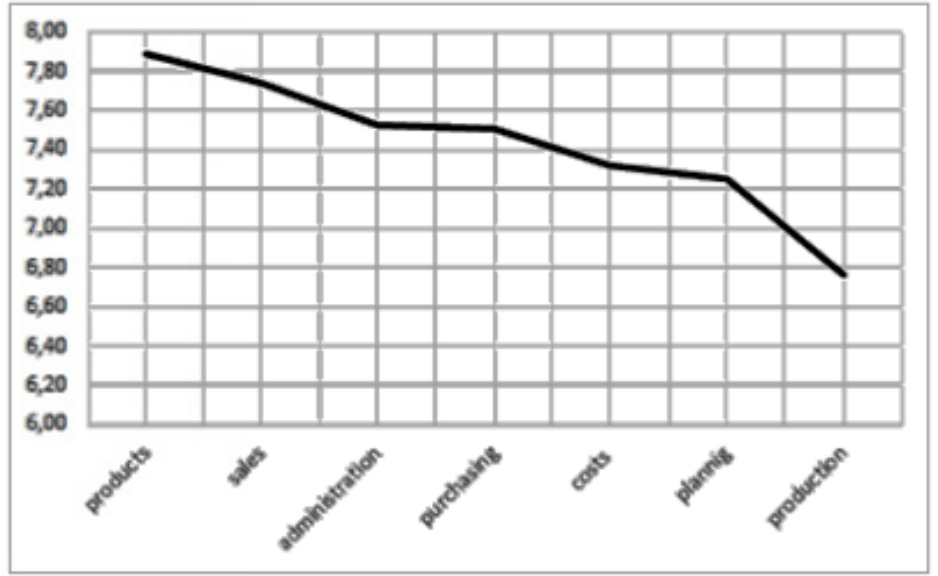

Fig. 2. Internal Factors Importance for the Sustainability of SMEs

Table 1. Values assigned to Internal Factors, per Region

\begin{tabular}{|c|c|c|c|c|c|}
\hline $\begin{array}{c}\text { Company } \\
\text { sectors }\end{array}$ & $\begin{array}{c}\text { Montes } \\
\text { Claros }\end{array}$ & Fortaleza & $\begin{array}{c}\text { Juazeiro } \\
\text { do Norte }\end{array}$ & Araxá & Total \\
\hline product & 8.43 & 9.00 & 7.75 & 6.38 & $\mathbf{7 . 8 9}$ \\
\hline sales & 8.13 & 8.31 & 7.00 & 7.54 & $\mathbf{7 . 7 5}$ \\
\hline administration & 8.00 & 7.95 & 7.00 & 7.15 & $\mathbf{7 . 5 2}$ \\
\hline purchasing & 6.50 & 8.25 & 7.67 & 7.62 & $\mathbf{7 . 5 1}$ \\
\hline costs & 7.50 & 7.75 & 7.50 & 6.54 & $\mathbf{7 . 3 2}$ \\
\hline planning & 8.14 & 7.71 & 6.00 & 7.15 & $\mathbf{7 . 2 5}$ \\
\hline production & 5.50 & 6.63 & 7.67 & 7.23 & $\mathbf{6 . 7 6}$ \\
\hline
\end{tabular}

The Small and Medium Sized Enterprise importance in the national economic development. 
The Likert method was used adjusted as follows:

Table 2. Multiple Choice questions concerning External Factors to SMEs

\begin{tabular}{|c|c|c|c|c|c|}
\hline & $\begin{array}{l}\text { Of no } \\
\text { relevan } \\
\text { ce }\end{array}$ & $\begin{array}{l}\text { Of some } \\
\text { relevance }\end{array}$ & Relevant & $\begin{array}{l}\text { Of much } \\
\text { relevance }\end{array}$ & $\begin{array}{c}\text { Necessar } \\
y\end{array}$ \\
\hline $\begin{array}{c}\text { The SMEs importance } \\
\text { in the economic } \\
\text { growth and develop- } \\
\text { ment is: }\end{array}$ & & & & & \\
\hline $\begin{array}{l}\text { Public policies for the } \\
\text { growth and develop- } \\
\text { ment SMEs are: }\end{array}$ & & & & & \\
\hline $\begin{array}{c}\text { Posts of employment } \\
\text { generated by SMEs in } \\
\text { the national scenario } \\
\text { are: }\end{array}$ & & & & & \\
\hline $\begin{array}{l}\text { Contribution from non } \\
\text { governmental agen- } \\
\text { cies, for the growth of } \\
\text { SMEs are: }\end{array}$ & & & & & \\
\hline $\begin{array}{l}\text { Academic and technic- } \\
\text { al education at the } \\
\text { SMEs is considered: }\end{array}$ & & & & & \\
\hline $\begin{array}{l}\text { To be competitive in } \\
\text { the market is: }\end{array}$ & & & & & \\
\hline $\begin{array}{l}\text { Financial System con- } \\
\text { tribution for SMEs is: }\end{array}$ & & & & & \\
\hline
\end{tabular}

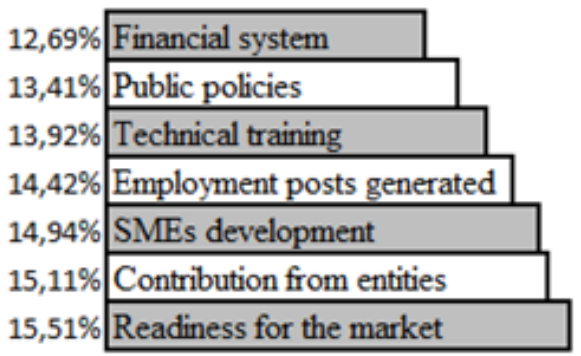

Fig. 3. External Factors classified by their importance to the SMEs

The preponderant external factor is to be well prepared to remain in the market, followed by the cooperation and support of class entities, the SMEs importance in the national scenario, employment posts generated by SMEs, capacitating of SMEs' labor, and support by the financial establishment. 
Table 3. Values assigned to External Factors according to Regions

\begin{tabular}{|c|c|c|c|c|c|c|}
\hline & $\begin{array}{c}\text { Montes } \\
\text { Claros }\end{array}$ & Fortaleza & $\begin{array}{c}\text { Juazeiro } \\
\text { do Norte }\end{array}$ & Araxá & Average & \\
\hline $\begin{array}{c}\text { To be prepared } \\
\text { for the market }\end{array}$ & 4.58 & 4.57 & 4.50 & 4.33 & $\mathbf{4 . 5 0}$ & $15.51 \%$ \\
\hline $\begin{array}{c}\text { Contributions } \\
\text { from entities }\end{array}$ & 4.42 & 4.43 & 4.33 & 4.33 & $\mathbf{4 . 3 8}$ & $15.11 \%$ \\
\hline $\begin{array}{c}\text { SMEs } \\
\text { development }\end{array}$ & 3.73 & 4.43 & 4.83 & 4.33 & $\mathbf{4 . 3 3}$ & $14.49 \%$ \\
\hline $\begin{array}{c}\text { Employment } \\
\text { posts generated }\end{array}$ & 4.31 & 4.30 & 4.17 & 3.94 & $\mathbf{4 . 1 8}$ & $14.42 \%$ \\
\hline $\begin{array}{c}\text { Technical } \\
\text { trainning }\end{array}$ & 3.92 & 4.22 & 3.67 & 4.33 & $\mathbf{4 . 0 4}$ & $13.92 \%$ \\
\hline Public policies & 4.08 & 9.96 & 4.00 & 3.50 & $\mathbf{3 . 8 9}$ & $13.41 \%$ \\
\hline $\begin{array}{c}\text { Financial } \\
\text { System }\end{array}$ & 3.25 & 3.52 & 3.50 & 4.44 & $\mathbf{3 . 6 8}$ & $12.69 \%$ \\
\hline
\end{tabular}

\section{$4 \quad$ Analysis and Discussion}

With reference to the internal factors that influence the sustainability of the SMEs, the products to be offered to the market are the main factor, and this leads to a competitive market, as far as the product's performance; however factors like costs and production and delivery times were not mentioned by the participants in the research. This brings up the commercial nature of the SMEs. Quite obviously, the objective of having a competitive product is to make sure it will be sold well, and that appears as second in importance in the research. Even services and industries show this type of focus. The numbers also show that to administration and purchasing is assigned quite well the same importance, and actually the ones interviewed believe that to buy efficiently is synonymous to administer efficiently. Costs are considered a consequence of purchasing, and here it means the buying of materials and labor. The planning factor is viewed as something operational, rather than strategic, and to production the same reasoning is applied.

Commercial activities, as an end in themselves, are important for SMEs' performance and sustainability in the market, but these activities add no value. Considering that the SMEs are responsible for the structural employment in Brazil, activities that add no value have the tendency of forcing the market into imports, and it would focus the economy's sustainability exclusively on the country's internal consumption.

Among external factors, the one of least importance is the expected support from the financial establishment. Due to high financial burdens, enterprises do their best to remain as capitalized as possible. Also, as a low importance factor, is the expectation of help from public policies aimed at SMEs; actually a degree of skepticism is noticed as far as this question is concerned. On the other hand, class associations, support from institutions as SENAI and SESC are recognized as of great usefulness to the 
SMEs and a real factor of development, even though the technical training supplied by these institutions many a time is not considered by managers as of relevant importance. This reasoning derives from the fact that managers do not see collaborators as SMEs development agents; they consider that only their own capacitating and expertise are decisive factors for the development of SMEs. These findings open a gap for further research, enabling a better understanding of the characteristics of these factors, pointing the need of the development of public policies towards new strategies of business enterprises in these sizes.

\section{References}

1. SEBRAE

http: / / www. sebrae.com.br/customizado/

estudos-e-pesquisas/temasestratégicos/sobrevivência

2. Bakos, L.: Decision-making and Managerial Behaviour Regarding Corporate Social Responsability in the Case of Small and Middle-sized companies. In: Procedia- Social Behavioral Sciences (2014)

3. Gonzáles, G.P.: Asociación Significativa entre los Modos de Conversión de Conocimiento y los Modelos de Decisión en las PYMEs de Cali- Colombia - Estudios Gerenciales Universidad ICESI Colombia (2011)

4. Pellešováa, P.: Position of Small and Medium Companies in Poland and Results of Research in Selected Areas.- Science Direct Contemporary Issues in Business, Management and Education (2013)

5. Kostkaa, G.: Barriers to Increasing Energi Efficiency: Evidence from Small and Mediumsized Enterprizes in China. Journal of Cleaner Production (2013)

6. Alvarado, T.E.G., Granados, M.A.M.: La innovación en Entornos Económicos Poco Favorables: El Sector Auto Partes Mexicano - Estudios Gerenciales Elsevier.es (2013)

7. Mendes Junior, J.N., Ferreira, M.C.: Análise Compreensiva: Conceito e Método, Rio Claro (2010) 